\title{
低侵襲手術トレーニングシステムの開発
}

\section{Development of Training System for Minimally Invasive Surgery}

正 $\bigcirc$ 中西 義孝・熊本大学大学院自然科学研究科

Yoshitaka NAKANISHI, Graduate School of Science and Technology, Kumamoto Univ.

非 三浦 裕正・九州大学大学院医学研究院

非 圓井 健敏・株式会社マルイ

Hiromasa MIURA, Graduate School of Medical Science, Kyushu Univ.

Taketoshi MARUI, MARUI Co.,Ltd.

正 拤 睦・熊本大学大学院

Mutsumi TOUGE, Kumamoto Univ.
非 久保田 章亀・熊本大学大学院

Akihisa KUBOTA, Kumamoto Univ.
正 日垣 秀彦・ 九州産業大学

Hidehiko HIGAKI, Kyushu Sangyo Univ.

Key Words: Training System, Arthroscopic Surgery, Box Training, Minimally Invasive Surgery, Product Planning

\section{1.はじめに}

整形外科領域における関節鏡手術は, 1980 年代以降膝関節 を中心に急激な進歩を遂げ, 現在では, 局, 手, 股関節など 広範囲に適用が広がっている。これらの低侵襲手術への流れ は, 近年の早期離床・早期リハビリテーションの必要性によ り，ますます加速しつつある。しかし，低侵襲手術は, 術野 の展開が制限され手術操作の自由度が低いため, より高度な 技術が要求され, 場合によっては未熟な手技による術中, 術 後合併症などの発生も危惧される.

一方，現在のわが国における関節鏡技術の教育システムは 手術中の指導医による指導と, 散発的に実施される教育・研 修セミナーによる教育のみで, トレーニング機会の絶対的不 足が問題である.また関節鏡技術に対する定量的かつ客観的 な評価システムは存在せず，高度な関節鏡技術教育のための 環境整備は不十分と言わざるを得ない.

著者らはこのような現況を鑑み, 機械工学技術を積極的に 導入した関節鏡総合トレーニングシステムの開発を行って いる．本報では，その概要を紹介するとともに，「死の谷」 や「ダーウィンの海」を克服するための取り組みを構成シス テムの1つである Box Training Systemを例にとり紹介する.

\section{2.関節鏡䁘合トレーニングシステム}

2-1. システム構成＼cjkstart関節鏡総合トレーニングシステムを 図 1 に示す, トレーニングシステムは，(A)Box Training ${ }^{1)}$ : 関節鏡手術に必要な個別技能（タスク）を集中的に訓練, (B) VR Training : (A)の重点タスクおよび (C)への対応可能性 を自動判定，(C) Knee Model Training ${ }^{2)}$ ：6軸力・位置検出 センサ付き生体膝モデルと実際の手術器具を用いた訓練,

(D)Practical Training : 生体膝の各種特性を忠実に再現し たモデルと実際の手術器具を用いた訓練，にて構成される.

(A) と (D)については, ビジネス展開のステージに入ってお り,「死の谷」や「ダーウィンの海」と称される各種障壁の 克服を行っている.（B)については力覚ディスプレイによる リアルな感覚提供システム, (C)については熟達度を自動判 定できるソフトウエア，について研究開発を行っている.

2-2. Box Training System 本システムは九州大学病院 のトレーニングセミナーでレギュラーメニューとして利用 されている。「試作システム（図 1)」にて開発コンセプトの 妥当性チェックが，「実用化システム（図 2)」にて耐久性の チェックや市場調査が，それぞれ完了しており，「ビジネス 展開システム (図 3，4)」への移行を行っている途中である.

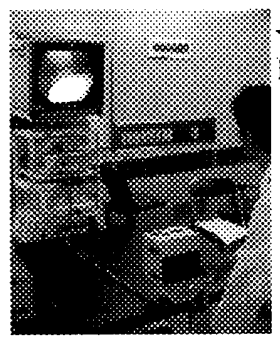

$<A$ : Box Training > Pre-training for individual tasks

$\angle B$ : VR Training $>$ Complicated \& voluntary training
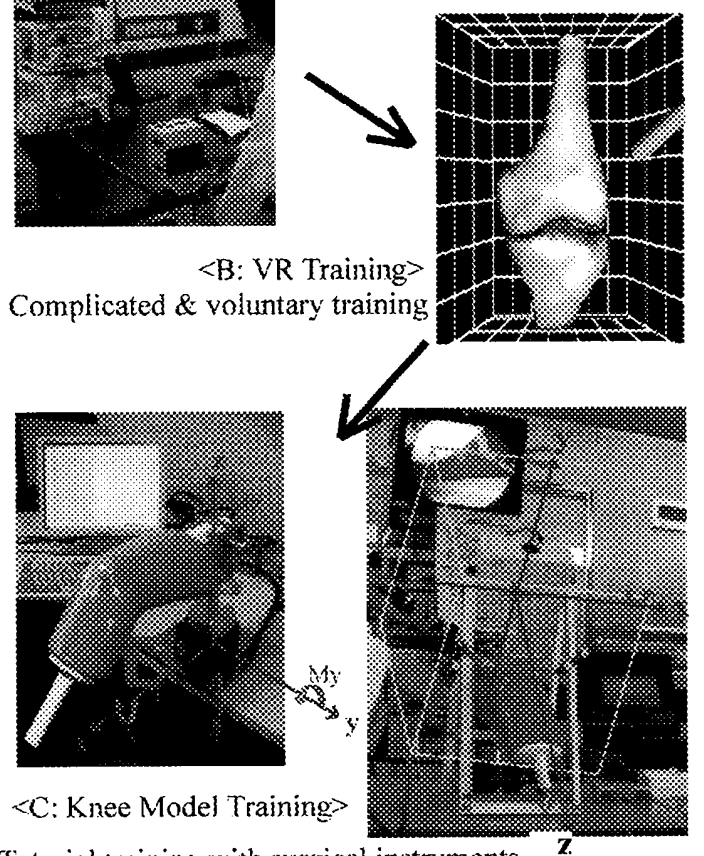

Tutorial training with surgical instruments

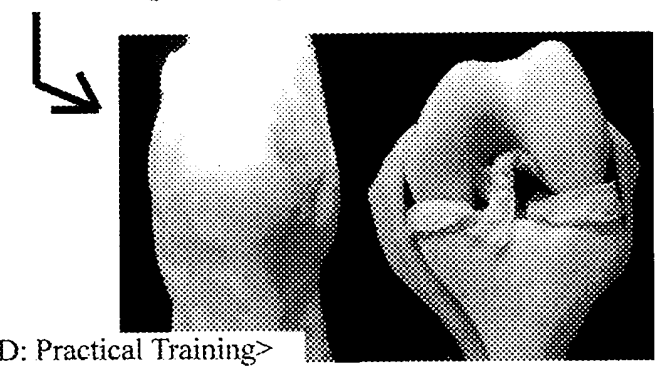

Detailed knee model \& surgical instruments

Fig.1 Universal training system for arthroscopic surgery.

Box Training System はシステム本体に訓練したい Task Box を挿入し使用する。単純な鏡視, 鉗子, 八サミ操作を訓 


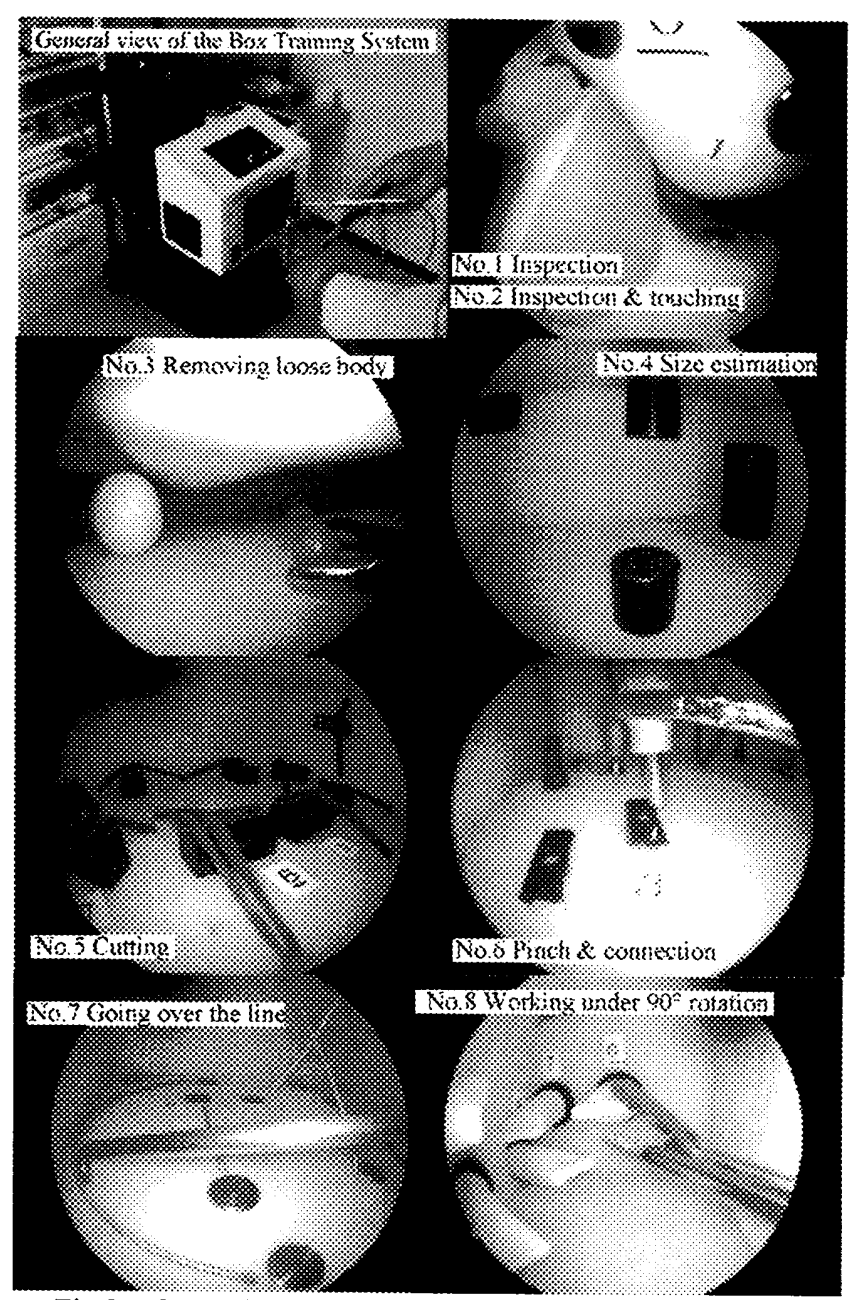

Fig.2 General view of the practical system and task boxes.

練するタスクから解剖学的位置情報の把握が必要なタスク まで, 合計 8 種類が準備（図 2) されており，システム本体 の指示に従って訓練することで，スコア/エラー数/作業時間 などの客観的指標が表示される仕組みになっている.

関節鏡トレーニングコースを受講した関節鏡手術経験 20 例以下のレジデント医師 6 名に対するトレーニングにおい ては，専門医が鏡視技術が低いと評価した術者は，90 度回転 下での鉗子操作（図 2 : No. 8) が苦手で, 電極接続タスク（図 2 : No. 6) にも時間がかかることが明らかとなっている。 また，専門医が両手協調運動が低いと評価した術者は，鏡視 タスク（図 2 : No. 1) や電極接続タスクに時間がかかるこ と，損傷・合併症を起こしやすいと評価された術者は，鏡視 \&タッチ（図 2 : No. 2 ）や電極接続のタスクが不得手であ ることも明らかとなっており，関節鏡技術向上に必要な能力 の特定やその能力の集中トレーニングにも Box Training が 有用であることが示されている.

\section{Box Training System の「死の谷/ダーウィンの海」}

「実用化システム（図 2)」の運用は，既に開発グループ の管理を離れ, トレーニングセミナー運営スタッフのみにて 行われており，取り扱い性や耐久性についてはビジネス展開 が可能なレベルに達している.

トレーニングセミナー参加者を中心とした市場調査によ れば,ビジネス展開における最大の障壁は販売価格であるこ とが明らかとなった. 現状の「実用化システム」の販売価格 は 400 万円/セットであるが，これが 150 万円になれば施設 に導入したいとの意見が大多数であった。仮にこの販売価格 が実現し，海外展開をおこなったとしても販売台数予測は 6, 000 セット程度（総売上価格：90 億円程度）であり, 従来 の大量生産・在庫保有方式による製造コスト低隇策をとるこ

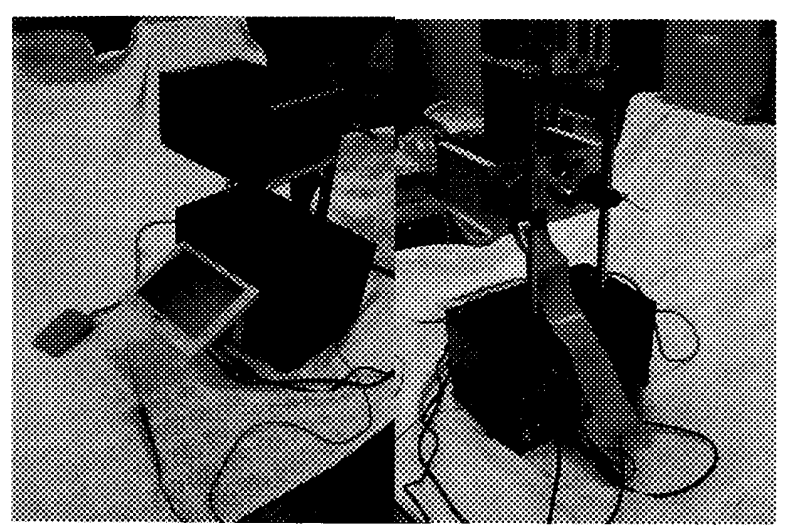

Fig.3 General view of the commercial system.

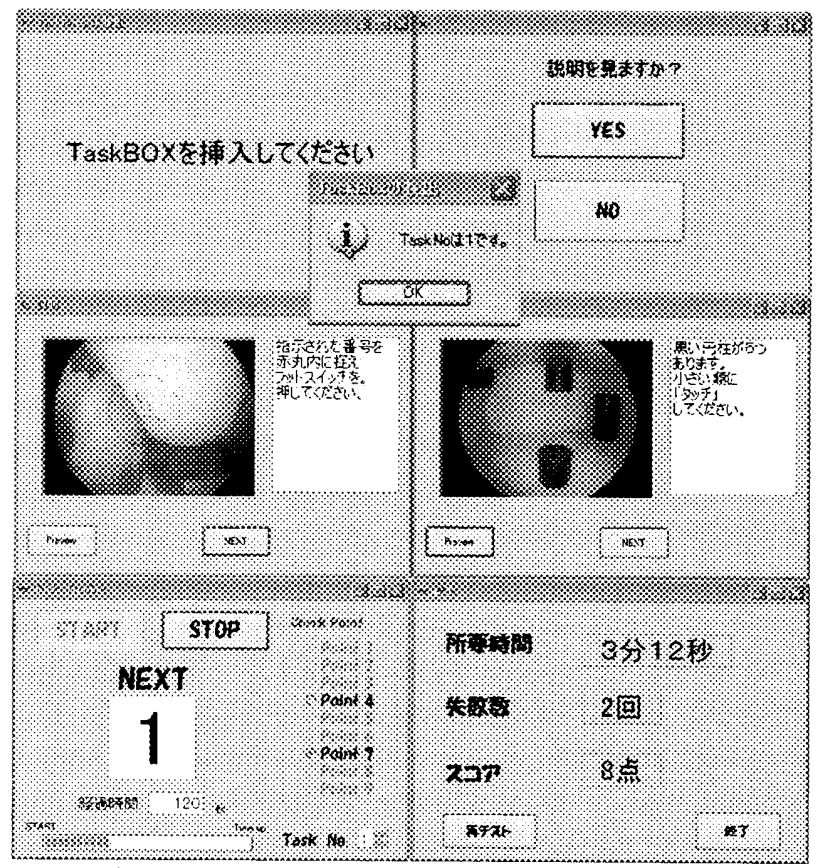

Fig.4 GUI for operating the commercial system.

\section{とは不可能であることも判明した。}

受注生産体制で利潤が確保でき，かつ，販売価格の大幅ダ ウンを実現する方法として,「ビジネス展開システム (図 3)」では徹底的な汎用部品/製品の活用を実践している. 例 えば, 量産化を視野に専用制御基板の開発・導入を行ったが, これを維持すれば 80 万円/セットの製造費が必要であった。 対策として，PC 用 ATX ボードと PCI バス用 I0 基板への变更 を行い，制御プログラムを $\mathrm{C}^{\#}$ 環境で開発した結果，約 60 万 円/セットのコストダウンが可能となった．また，表示シス テムも専用 LCD を開発・導入していたが, タッチパネル式汎 用ディスプレイに切り替えることで，コスト増加を招くこと なく，操作性に優れた GUI 環境を実現することができた。

2010 年 3 月末をメドに少なくとも国内 2 ～ 3 機関(医療機 関）での試験販売を実施予定にしている. 本活動が医療支援 機器などのビジネスモデル例となることを期待している.

\section{考文献}

1) Y. NAKANISHI, Y. TASHIRO, H. MIURA, T. TAKASHIMA, H. HIGAKI, K. OKAZAKI, S. MATSUDA, S. HAMAI, K. TANOUE, M. HASHIZUME, Y. IWAMOTO: Box Training System for Arthroscopic Surgery. Proc. $4^{\text {th }}$ Asian Pacific Conference on Biomechanics, pp. 184-185, 2009.

2 ) Y. Tashiro, H. Miura, Y. Nakanishi, K. Okazaki, Y. Iwamoto: Evaluation of Skills in Arthroscopic Training Based on Trajectory and Force Data. Clin Orthop Relat Res. Vol. 467, No. 2, pp. 546-552, 2009. 